\title{
Diphacinone with cholecalciferol for controlling possums and ship rats
}

\author{
Charles Eason $^{a, b}$, Lee Shapiro ${ }^{b, c}$, Candida Eason ${ }^{c}$, Duncan MacMorran $^{c}$ and \\ James Ross (D) \\ ${ }^{a}$ Cawthron Institute, Nelson, New Zealand; ${ }^{b}$ Centre for Wildlife Management and Conservation, Lincoln \\ University, Lincoln, Canterbury, New Zealand; 'Connovation Ltd., Manukau, New Zealand
}

\begin{abstract}
Potent second-generation anticoagulant rodenticides such as brodifacoum have been used as more effective alternatives to first-generation anticoagulants, such as warfarin. A combination of diphacinone at $0.005 \%$ and cholecalciferol at $0.06 \%$ produces a slow-acting bait that is effective at killing possums (Trichosurus vulpecula) and rodents. Cage trials with groups of possums and ship rats (Rattus rattus) achieved a mortality of $87 \%$ and $86 \%$ for possums and ship rats, respectively. Two field trials, each 200 hectares in size, targeting possums, ship rats and mice achieved an average reduction in the abundance of $94 \%$ for possums, $94 \%$ for ship rats and $80 \%$ for mice. The combination of diphacinone and cholecalciferol appears effective and has a favourable risk profile compared with second-generation anticoagulant rodenticides, such as brodifacoum. Approval of this new bait by the New Zealand Environmental Protection Agency was granted in 2018 and final registration obtained from the Ministry of Primary Industries in 2019.
\end{abstract}

\section{ARTICLE HISTORY}

Received 17 May 2019

Accepted 14 August 2019

\section{HANDLING EDITOR}

Chris Jones

\section{KEYWORDS}

Cholecalciferol; combination; diphacinone; Rattus rattus; toxicology; Trichosurus vulpecula; vertebrate pesticide

\section{Introduction}

Prior to 1950 all vertebrate pesticides used worldwide were non-anticoagulants, most of them acute or quick acting, but after the introduction of warfarin and the other anticoagulants, the importance of these non-anticoagulants was somewhat reduced, at least for rodent control (Eason et al. 2017). However, in New Zealand, because of our conservation needs and TB management challenges (Livingstone et al. 2015) there are six acute acting poisons currently registered for possum control: 1080 (sodium fluoroacetate), cyanide, cholecalciferol (Vitamin $\mathrm{D}_{3}$ ), zinc phosphide, sodium nitrite and phosphorus. 1080 and cholecalciferol can be used for the control of rodents as well as possums. Sodium nitrite has been developed for control of possums and feral pigs and is particularly humane comparing well with cyanide (Shapiro et al. 2016). In an optimised mammalian pest control tool box there will be both fast-acting acute toxins and slower acting anticoagulants (Eason et al. 2017), for example, where maintenance control of low-density possum populations and long-term suppression or elimination of possum populations is a requirement, and 
neophobia or trap or bait-shyness may develop if acute toxins or traps are used repeatedly. Globally, anticoagulants have been used for control of commensal rodents, primarily Norway rats (Rattus norvegicus), ship rats (Rattus rattus) and house mice (Mus musculus). Brodifacoum is the most widely used slow-acting rodenticide worldwide and is highly effective for controlling both rodents and possums. Two anticoagulants are registered for possum and rodent control, namely brodifacoum and pindone. However, first-generation anticoagulants like pindone or diphacinone are not effective against possums at current bait concentrations (Eason et al. 1994, 2017). The anticoagulant effect of these compounds in possums is quite different from that seen in rats. For example, after a lethal dose of brodifacoum most rats will die within a week whereas, possums will take 2-4 weeks to die (Littin et al. 2002). Additionally, very large amounts of baits containing first-generation anticoagulants alone have to be eaten by possums compared with rats for baits to be effective which is costly, and combined with their questionable effectiveness the only anticoagulant effective for controlling possums is brodifacoum (Eason et al. 2017).

Unfortunately, brodifacoum and other second-generation anticoagulants have a tendency to bioaccumulate and cause secondary poisoning which has advantages in some situations, but not where there are concerns regarding residues, food safety and non-target impacts (Eason et al. 1996, 1999, 2010a, 2010b). Widespread second-generation anticoagulant exposure in non-target species has been documented globally, including the USA (Murray 2011), Norway (Langford et al. 2013), Denmark (Christensen et al. 2012), Great Britain (Walker et al. 2014), Spain (Lopez-Perea et al. 2015), Australia (Young and De Lai 1997), New Zealand (Eason et al. 1999) and Malaysia (Salim et al. 2015) and in some cases long-term studies have explicitly demonstrated an increasing trend in exposure incidence and residue concentration over time (Walker et al. 2014). Persistence has been associated with wildlife contamination of native birds as well as game species (Young and De Lai 1997; Eason et al. 1999, 2002, 2010a; Stone et al. 1999, 2010b, 2017; US EPA 2008).

Hence, there has been an interest in researching the combination of the first-generation anticoagulant with cholecalciferol, as this combination has been proven to be effective in rodents resistant to first-generation anticoagulants alone (Pospischil and Schnorbach 1994). The potential to produce bait that is as potent as brodifacoum for possum and rodent control (Eason et al. 2008), without significant residue concerns is important. A bait containing diphacinone and a very small amount of cholecalciferol, as an additive, will potentially meet the specification of being 'low residue' (i.e. less persistent), slowacting, lower cost and should be safer for non-target species. It has been developed in New Zealand for the control of possums and rats and in parallel has been researched for the control of California voles (Microtus californicus), an agricultural pest in the US (Witmer et al. 2014; Baldwin et al. 2016).

Diphacinone has been identified as the anticoagulant of choice for this combination bait because of its short half-life (Crowell et al. 2013). Diphacinone is a first-generation anticoagulant toxin that was developed in the USA and first used in New Zealand in the 1950s. Cholecalciferol (vitamin $\mathrm{D}_{3}$ ) was developed in the 1980s as a rodenticide (Marshall 1984; Tobin et al. 1993). Cholecalciferol is registered in New Zealand for rodent and possum control in baits at $0.8 \%$ and $0.4 \%$. It is registered under the trade name of Terad $3^{\oplus}$ $(0.075 \%$ cholecalciferol $)$ in the USA, and in Europe it has, as mentioned above, been added to baits containing a first-generation anticoagulant, namely coumatetralyl (Racumin ${ }^{\oplus}$ plus) to overcome anticoagulant resistance in rats and mice (Pospischil and Schnorbach 1994). 
The bait containing diphacinone at $0.005 \%$ and cholecalciferol at $0.06 \%$. $(\mathrm{D}+\mathrm{C})$ has been developed as a 'lower risk' alternative to baits containing brodifacoum at $0.002 \%$ (PestOff $^{\circ}$ solid cereal bait). Diphacinone is also considerably less persistent than coumatetralyl. More detailed reviews of the characteristics, international application and toxicology of these compounds can be found elsewhere (Prakash 1998; Hayes and Laws 1991; Eason et al. 2010a, 2017; Buckle and Eason 2015). This paper contains details of cage and pilot field trials on the effectiveness of paste bait at controlling possums and ship rats and a 'desktop' risk versus benefit assessment of secondary poisoning, residues and non-target risks. In New Zealand forests, house mice are a key food source for stoats (Mustela erminea) and feral cats (Felis catus) and the high numbers of mice directly contribute to higher rates of predation for native birds (Ruscoe and Murphy 2005). Due to this, we also monitored the numbers of mice in the field trial to assess the potential of this compound for mice control.

\section{Methods}

There are two experiment sections, covering cage and pilot field trials and one desk top risk analysis section based on a literature review. Solid extruded cereal baits containing a combination of diphacinone at $0.005 \%$ and cholecalciferol at $0.06 \%(D+C)$ were prepared by Connovation Ltd., East Tamaki, Auckland, New Zealand and used for all the trials described below. Prior to cage and field trials, a sample of bait was assayed by Landcare Research who confirmed the concentrations of the diphacinone (Assay T5931) and cholecalciferol (Assay T5930) active ingredients.

\section{Cage trials}

Sixteen possums and 16 ship rats were captured from the wild and transported to the Centre for Wildlife Management and Conservation (CWMC) possum enclosures at the Johnston Memorial Animal Facility at Lincoln University. On arrival, possums were sedated and given a health check, sexed and then individually housed. Possums were fed a maintenance diet (loose cereal mix) with water available ad libitum (following SOP \#86 Possum Husbandry). Possums were acclimatised for 10 days prior to the trial and one possum was excluded from the trial as it was not eating well during the acclimatisation period. The remaining 15 possums have lightly fasted with reduced rations for $12 \mathrm{~h}$ before the baits were presented. Individual possums were presented with approximately $200 \mathrm{~g}$ of solid extruded D $+\mathrm{C}$ bait in a no-choice test. Baits were weighed and then presented in the afternoon and then weighed again and removed first thing the following morning. Normal maintenance diet was then resumed and the animals observed regularly.

Rats were fed grain pellets daily and water was available ad libitum (following SOP \#36 Rat Husbandry). Two rats escaped from their cages the night of the trial and they were excluded from the trial analysis. The remaining 14 rats were also lightly fasted on reduced rations for $12 \mathrm{~h}$ before the baits were presented. Individual rats were presented with approximately $100 \mathrm{~g}$ of solid extruded $\mathrm{D}+\mathrm{C}$ bait. Baits were weighed and then presented in the afternoon and then weighed again and removed first thing the following morning. After the completion of the exposure, period rats were returned to their standard diet and observed regularly. 


\section{Field trials}

Field trials were small-scale pilot studies designed to consolidate the cage trial data to enable product registration. Two trial sites, each 200 ha in size and separated by $500 \mathrm{~m}$, were set up in Opepe Forest located approximately $30 \mathrm{~km}$ south east of Taupo. A non-treatment site also 200 ha was established $1 \mathrm{~km}$ away. The three sites consisted predominantly of plantation pine (Pinus radiata) with some native scrub. Each site was monitored for possum and rodent abundance prior to the start of the trial. The relative possum abundance was measured pre- and post-poisoning using residual trap catch index (RTCI), which indicates the number of possums trapped per 100 trap nights after adjustments are made for traps being 'sprung' or catching non-target species (NPCA 2015), using Victor ${ }^{\mathrm{TM}}$ No. 1 sized double-coil spring traps. Each of the three sites (two treatments and one control) were set up with five lines of traps with 10 traps per line at $20 \mathrm{~m}$ intervals. Each line was at least $200 \mathrm{~m}$ from other trap lines for statistical independence. Rodent abundance was monitored pre- and post-poisoning using tracking tunnels, plastic run-through tunnels with ink cards inside to record paw prints, set up on lines with 10 tunnels per line and $50 \mathrm{~m}$ between each tunnel. Each of the three sites (two treatments and one control) were set up with five lines of tracking tunnels. The use of these tunnels followed best practice (Gillies and Williams 2013) and tunnels were baited with peanut butter and left out for a single night and each line was $100 \mathrm{~m}$ apart for statistical independence. The tracking rates were expressed as the percentage of tunnels in each area tracked by a given species (Blackwell et al. 2002) and adjustments to the percentage kill estimates for possums and rats were made allowing for the natural changes observed at the control site (Morgan 2006). The trial, which included the pre- and post-monitor of target species as well as the two months of toxic baiting, which is standard practice for anticoagulant baiting, ran from May 2015 until early August 2015. During the period of toxic baiting, the average daily rainfall was $5.2 \mathrm{~mm}$ (total rainfall was $317.8 \mathrm{~mm}$ ) and the average overnight temperature was $2.9^{\circ} \mathrm{C}$.

Two hundred Philproof bait stations were used in each of the treatment blocks, at a spacing of one per ha, and each loaded with $1 \mathrm{~kg}$ of $\mathrm{D}+\mathrm{C}$ bait. After one month bait stations were checked and baits weighed, and all bait stations topped up to $1 \mathrm{~kg}$. After bait had been in stations in the field for two months it was removed. Over the course of the trial three motion-activated infrared cameras (Ltl Acorn model 5210) were used to monitor the activity of target and non-target species at bait stations; these cameras were moved to different bait stations every two weeks. When bait was removed, the field research team looked for carcasses of target species and non-target species when moving between bait stations at each site. Once all bait was removed possum and rodent abundance was monitored following the same protocols for both species as the pre monitor described above.

Lincoln University Animal Ethics Committee (AEC) approval was obtained for all the trials. AEC 594 and 597 covered cage and field trials.

\section{Literature review}

Standard literature review approaches were used to further assess the risk and welfare impact of the new baits versus other existing products. Prior to research on diphacinone and cholecalciferol in a combination, we were pursuing a combination of coumatetralyl 
and cholecalciferol; however, this was discontinued in favour of diphacinone and cholecalciferol, as diphacinone is less persistent and more palatable (Sam and Ross 2012). Bait containing $0.06 \%$ cholecalciferol and $0.005 \%$ diphacinone has been developed, and dossiers have been filed with the Environmental Protection Agency (EPA) late in 2015 to support the registration of solid bait effective at killing possums and rodents with similar potency to brodifacoum (Eason et al. 2017). Because a substantial amount of research was undertaken on the combination of coumatetralyl and cholecalciferol, before research was redirected to the preferred combination of diphacinone and cholecalciferol, and because the coumatetralyl and cholecalciferol combination has a similar potency and risk profile to diphacinone and cholecalciferol, reference to some of the earlier work on coumatetralyl and cholecalciferol was reviewed.

\section{Results}

\section{Cage trials}

Possums ate an average of $71.1 \mathrm{~g}$ of $\mathrm{D}+\mathrm{C}$ bait and $86.67 \%(13 / 15)$ of possums died within 5-7 days after consuming bait (Table 1). Symptoms were not evident until two days before death. Over the two-day period prior to death (Table 1) symptoms included lethargy, crouching and excessive salivation and laboured breathing.

Ship rats ate an average of $10.6 \mathrm{~g}$ of $\mathrm{D}+\mathrm{C}$ bait and $85.71 \%(12 / 14)$ died within 3-9 days after consuming bait (Table 1). In the $24 \mathrm{~h}$ prior to death (Table 1) symptoms included hunched posture, rough coat/pilo-erection and some fluid discharge from the eyes and nose.

Post-mortem assessment of rats showed substantial haemorrhaging. However, the possum is less susceptible to the haemorrhagic effect of anticoagulants, but more susceptible to cholecalciferol and post-mortem assessment of possums showed a combination of tissue calcification with some haemorrhaging.

\section{Field trials}

At site one, after treatment with bait, adjusted possum abundance dropped by $95 \%$, ship rat abundance by $88 \%$ and mouse abundance by $80 \%$ (Table 2). A total of $35 \mathrm{~kg}$ of bait was consumed at site one over the two-month trial. At site two after bait treatment adjusted

Table 1. Average amounts of diphacinone and cholecalciferol consumed, times of behaviour changes, death and efficacy of bait for possums and ship rats.

\begin{tabular}{lll}
\hline Feature & \multicolumn{1}{c}{ Possums } & \multicolumn{1}{c}{ Rats } \\
\hline Amount of diphacinone consumed (mg ai/kg body weight) & 1.29 (range 0.46-2.47) & 4.51 (range 2.64-8.33) \\
Amount of cholecalciferol consumed (mg ai/kg body weight) & 15.50 (range 5.53-29.61) & 54.10 (range 31.64-100.00) \\
Time of reduced feed intake (days after initial ingestion) & 4 (2 days prior to & 2 (3 days prior to death) \\
& death) & \\
Time of reduced activity/symptoms (days after initial ingestion) & 4 (2 days prior to & 4 (24 h prior to death) \\
& death) & \\
Change in weight over course of trial (\% weight change from start & 5.96 (range +8.29 to & 11.54 (range -3.25 to \\
to death/finish) & $-9.86)$ & -18.85 ) \\
Number of animals killed & $13 / 15$ & $12 / 14$ \\
Time until death (days after initial ingestion) & 5.77 (range 5-7) & 5.08 (range 3-9) \\
\hline
\end{tabular}


Table 2. Pre- and post-monitoring of ship rat and possum abundance and \% reduction with and without adjustments to the percentage kill estimates - based on change at the control sites.

\begin{tabular}{llcccc}
\hline Site & Species & Pre monitor & Post-monitoring & \% reduction not adjusted & \% reduction adjusted \\
\hline 1 & Possums & $6.66 \%$ & $0.66 \%$ & $90 \%$ & $95 \%$ \\
1 & Ship rats & $26.00 \%$ & $2.00 \%$ & $92 \%$ & $88 \%$ \\
1 & Mice & $44.00 \%$ & $6.00 \%$ & $86 \%$ & $80 \%$ \\
2 & Possums & $10.00 \%$ & $1.33 \%$ & $87 \%$ & $93 \%$ \\
2 & Ship rats & $12.00 \%$ & $0.00 \%$ & $100 \%$ & $100 \%$ \\
2 & Mice & $42.00 \%$ & $6.00 \%$ & $86 \%$ & $79 \%$ \\
Control & Possums & $2.03 \%$ & $4.00 \%$ & $\mathrm{n} / \mathrm{a}$ & $\mathrm{n} / \mathrm{a}$ \\
Control & Ship rats & $16.00 \%$ & $12.00 \%$ & $\mathrm{n} / \mathrm{a}$ & $\mathrm{n} / \mathrm{a}$ \\
Control & Mice & $30.00 \%$ & $20.00 \%$ & $\mathrm{n} / \mathrm{a}$ & $\mathrm{n} / \mathrm{a}$ \\
\hline
\end{tabular}

possum abundance dropped by $93 \%$, ship rat abundance by $100 \%$ and mouse abundance by $79 \%$ (Table 2). A total of $30 \mathrm{~kg}$ of bait was consumed at site two over the two-month trial. The three motion-activated infrared cameras recorded possums, ship rats and mice accessing bait stations and consuming bait. Several non-target species including blackbirds (Turdus merula), silver eyes (Zosterops lateralis), stoats and hedgehogs (Erinaceus europaeus) were recorded on cameras. However, none of these were observed accessing bait stations. During the removal of bait at both sites, carcasses of both possums and rats were found; however, no carcasses of non-target species were found.

\section{Literature review}

Our literature review identified extensive literature on the welfare impacts, mode of action, residues, secondary poisoning and non-targets risk of diphacinone and cholecalciferol and other vertebrate pesticides. This information is summarised below, and comparisons are made between the new combination and other vertebrate pesticides. Where appropriate the results described above are compared with published data and earlier reports.

\section{Welfare}

The time to death from previous cage trials with brodifacoum, diphacinone and cholecalciferol as sole agents (Littin et al. 2000), and from coumatetralyl and cholecalciferol trials are summarised below alongside our new data. The average time to death for rats and possums poisoned with the combination of diphacinone and cholecalciferol was similar or shorter than for brodifacoum alone and this is most apparent for possums.

With second-generation anticoagulants, such as brodifacoum, as sole agents, sickness is protracted and the duration of sickness and time to death variable (Littin et al. 2000). The authors concluded that the welfare of poisoned animals could be practically improved by shortening the time until death using drugs that potentiate the anticoagulant action. This aspiration by Littin et al. (2000) has been advanced with the new D + C bait (see Table 3).

\section{Mode of action}

Diphacinone is an anticoagulant vertebrate pesticide similar in toxic mechanism to other anticoagulants such as brodifacoum. It interferes with normal blood clotting by preventing vitamin $\mathrm{K}$ recycling which prevents the conversion of inactive precursors into active vitamin K-dependent blood-clotting factors (Thijssen 1995). Major haemorrhaging and death by respiratory or heart failure result following a lethal dose. Kerins et al. (2002) 
Table 3. Comparative average times to death for possums and rats.

\begin{tabular}{lccc}
\hline & \multicolumn{2}{c}{ Average time to death (days) } & \\
\cline { 2 - 4 } & Possums & Rats & Reference \\
\hline Brodifacoum & 20.1 & 7.2 & Littin et al. (2000) \\
Coumatetralyl+ Cholecalciferol & 11.1 & - & Sam and Ross (2012) \\
Cholecalciferol & - & 6.4 & Shapiro et al. (2011) \\
Cholecalciferol & 7.0 & & Hix (2009) \\
Diphacinone & - & 6.7 & Hix et al. (2010) \\
Diphacinone+ Cholecalciferol & 5.75 & 5.08 & This publication \\
\hline
\end{tabular}

suggest that a low dose of cholecalciferol enhances the haemorrhagic effect of first-generation anticoagulants. Post-mortem assessment of rats containing baits shows substantial haemorrhaging. Similar effects could be expected in most other species; however, the possum is less susceptible to the haemorrhagic effect of anticoagulants (Eason et al. 1994), and death in possums is likely to be caused by a combination of haemorrhaging and hypercalcaemia.

\section{Residues}

Vertebrate pesticides differ in the way they are absorbed, metabolised, distributed and excreted, as well as the length of time that these processes take in different animals. In the section below, we review in detail the published literature on diphacinone and cholecalciferol and then make comparisons with other commonly used toxins.

In a comparative study of rodenticides by Fisher et al. (2003), laboratory rats were given an oral dose of $1.5 \mathrm{mg} / \mathrm{kg}$ diphacinone and the hepatic elimination half-life was estimated at 3 days. Residues were present 1 week after dosing but were not detected 2 weeks after dosing. In a trial with ten pigs dosed at $1.5 \mathrm{mg} / \mathrm{kg}$, Crowell et al. (2013) estimated a mean hepatic elimination half-life of 12.4 days for diphacinone. Diphacinone residues in the liver were near or below the method's detection for a pair of pigs that were euthanised 28 days after dosing, and not detected at 43 days after dosing.

In pigs dosed at $12.5 \mathrm{mg} / \mathrm{kg}$ of diphacinone, Fisher (2006) calculated an initial and terminal hepatic elimination half-life in recognition that elimination of anticoagulants from the liver is often biphasic (i.e. an initial rapid phase followed by a slower terminal phase; Parmar et al. 1987). The initial elimination half-life in liver was estimated as 1.30 days and the terminal hepatic elimination half-life in liver was estimated as 14.1 days. Diphacinone was not cleared from the livers of three pigs that were sampled at 15 days after dosing. Three red deer (Cervus elaphus scoticus) were dosed at $1.5 \mathrm{mg} / \mathrm{kg}$ diphacinone and biopsied periodically by Crowell et al. (2013). A mean hepatic elimination halflife of 6.0 days was estimated, and diphacinone residues in the liver were not detected in two of three deer sampled at 12 days after dosing, and the third deer after 29 days (Crowell et al. 2013).

Studies on cattle suggest that they may excrete diphacinone significantly more slowly than other species. Bullard et al. (1976) dosed six Hereford cows with $1 \mathrm{mg} / \mathrm{kg}$ diphacinone by injecting it into the rumen and found that liver residues were almost identical when analysed at 30, 60 and 90 days after treatment $(0.14-0.15 \mathrm{mg} / \mathrm{kg})$. Crowell et al. (2013) carried out two trials in which cattle were dosed orally at $1.5 \mathrm{mg} / \mathrm{kg}$. In both trials, the maximum diphacinone concentration in the liver was much higher than that 
recorded in pigs and deer that had been given the same dose. A rapid initial decline in hepatic concentration was observed before it increased on either day 43 (first trial) or day 29 (second trial), and so initial elimination half-lives (day 0 to day 30) and terminal elimination half-lives (from day 30 onwards) were calculated for these trials. The mean terminal elimination half-lives were 25 and 35 days for the first and second trials respectively. Diphacinone residues in the liver were below the MDL for all animals by 155 days after dosing in the first trial and 125 days after dosing in the second trial. Based on studies where residues were tracked until no longer detected in liver, it is expected diphacinone would be no longer detected at about 40 days after dosing. The exception to this is in cattle, where it may be detected at least 3 times longer. This compares favourably with both brodifacoum and coumatetralyl (Fisher et al. 2003; Singleton et al. 2003).

Cholecalciferol residue studies. Cholecalciferol (Vitamin D3) is metabolised to 25-hydroxycholecalciferol (25-OHD) in the liver, with any surplus cholecalciferol either further metabolised and excreted in bile or stored in fat and muscle tissue (Parfitt et al. 1982; Holick 2003; Heaney et al. 2009). Further metabolism of 25-OHD in the kidneys produces 24, 25-dihydroxycholecalciferol or 1,25-dihydroxycholecalciferol (1,25-OHD or calcitriol).

25-OHD circulates in the blood and is the metabolite generally monitored to determine whether an animal has consumed cholecalciferol, as it is more stable and its concentration is more strongly correlated with cholecalciferol intake or synthesis than other metabolites (Fairweather et al. 2013). Because 25-OHD occurs naturally in animals, Fairweather et al. (2013) recommend excessive cholecalciferol consumption is indicated where 25-OHD residues in plasma or liver are at least four times as high as defined reference levels for particular species.

Persistence studies in possums orally dosed with $20 \mathrm{mg} / \mathrm{kg}$ cholecalciferol showed elevated concentrations of 25-OHD are likely to persist in plasma, heart, liver, kidney and fat for at least 29 days. 25-OHD levels declined in all tissues except fat between sampling on 3 days and 29 days after dosing (Eason et al. 1996). The authors had measured a concentration of 25-OHD in plasma prior to dosing, and residues were 15 times higher than this reference level by 29 days after dosing.

Brouwer et al. (1998) administered an oral dose of $37.5 \mu \mathrm{g}$ cholecalciferol (being 0.20$0.25 \mathrm{mg} / \mathrm{kg}$ ) daily for 14 days to female rats. The half-lives of cholecalciferol in plasma, perirenal and subcutaneous adipose tissue were 1.4, 97.3 and 80.9 days, respectively. The half-life of 25-OHD in plasma was calculated as 22.5 days. 25-OHD in plasma was still elevated 27 days after the final dose (i.e. on day 40), but by 63 days after the final dose, the 25-OHD concentration had returned to normal (Brouwer et al. 1998).

Cattle had raised 25-OHD levels 42 days after being injected intramuscularly with $375 \mathrm{mg}$ of cholecalciferol (Hollis et al. 1977). Brouwer et al. (1998) is the only study where depletion of 25-OHD was monitored until the level could be described as normal. This result is consistent with observations from other studies; we would expect elevated concentrations of 25-OHD to persist in mammals for approximately 63 days after dosing.

In all studies, diphacinone and cholecalciferol are depleted at faster rates when compared with brodifacoum. Diphacinone and cholecalciferol when used together in cereal 
pellet bait are therefore less likely to lead to persistent residues and bioaccumulation in livestock or game than brodifacoum.

Eason et al. (2010a) have previously classified these compounds into four groups, based on their persistence in sub-lethally exposed animals. The criteria for the four groups, and the allocation of different compounds to these groupings are described below and in Table 4 . Diphacinone falls in the low residue and cholecalciferol in the moderate category.

Group 1 -Very low residue risk compounds. Sub-lethal doses of these poisons are likely to be substantially cleared from the body within $24 \mathrm{~h}$ (e.g. cyanide, zinc phosphide, PAPP and 1080).

Group 2 - Low residue risk compounds. Residues resulting from sub-lethal doses of these poisons are likely to be substantially cleared from the body within 2-4 weeks (e.g. pindone and diphacinone).

Group 3 - Moderate residue risk compounds. Residues resulting from sub-lethal doses of these poisons are likely to be cleared from the body within 2-4 months (e.g. coumatetralyl). Cholecalciferol is unusual as it and the active metabolite 25-OHD will be present in blood and tissue of all animals at background reference levels (Fairweather et al. 2013) and retained residues will present low risk when they return to normal levels in healthy animals surviving exposure to bait, hence whilst its half-life implies moderate residue risk it does not really fit this type of classification, which is more appropriate for a xenobiotic.

Group 4 - High residue risk compounds. Residues resulting from sub-lethal doses of these poisons may not ever be completely cleared from the body (e.g. bromadiolone, brodifacoum and flocoumafen). There is additional risk of acquiring and retaining residues from secondary poisoning or tertiary poisoning as well as from baits with these compounds.

\section{Secondary poisoning and non-target risk}

The tendency to bioaccumulate is linked with non-target and secondary poisoning risks and clearly, this risk, as indicated in Table 4 above, will be less for $\mathrm{D}+\mathrm{C}$ baits versus brodifacoum. There is also much less risk of secondary poisoning of non-target species from carcasses or sub-lethally poisoned animals.

Table 4. Classification of vertebrate pesticides based on comparative pharmacokinetics and expectation of persistence of residues in sub-lethally exposed species (adapted from Eason et al. 2010b).

\begin{tabular}{llll}
\hline Group & \multicolumn{1}{c}{ Compound } & Half-life values & Likely persistence of residues in edible tissues \\
\hline 1 & Cyanide & + & $12-24 \mathrm{~h}$ \\
& Zinc phosphide & + & $12-24 \mathrm{~h}$ \\
& Para-aminopropiophenone & + & 4 days \\
& 1080 & $<11 \mathrm{~h}$ & 7 days \\
3 & Pindone & 2.1 days & 4 weeks \\
& Diphacinone & 3 days in rats & 6 weeks \\
& Cholecalciferol & $10-68$ days & 3 months but note: it is always present \\
& Coumatetralyl & & at normal physiological concentrations \\
4 & Brodifacoum & $50-70$ days & 4 months \\
& Bromodiolone & 130 days & 24 months or longer \\
& Flocoumafen & 170 days & 24 months or longer \\
& 220 days & 24 months or longer \\
\hline
\end{tabular}

Note: + no published value but likely to be $<12 \mathrm{~h}$. 
Secondary poisoning risk from diphacinone and cholecalciferol as sole agents in carcasses has previously been shown to be low (Eason et al. 2013) when compared to compounds like 1080 and brodifacoum. This earlier work with diphacinone and cholecalciferol as sole agents has also shown secondary poisoning risks to birds, dogs and cats to be low (Eason et al. 2000, 2013; US EPA 2008; Lima and Salmon 2010). However, there are no published reports on the $\mathrm{D}+\mathrm{C}$ combination and secondary poisoning and non-target risk. Nevertheless, as mentioned previously the combination of coumatetralyl $(0.03 \% \mathrm{w} / \mathrm{w})$ and cholecalciferol $(0.015 \% \mathrm{w} / \mathrm{w})$ was extensively studied prior to the realisation that diphacinone and cholecalciferol would be a safer alternative (Crowell et al. 2013). For example, secondary poisoning studies were conducted with poisoned carcasses fed to chickens and dogs and non-target species were exposed to bait (Henderson 2006, 2009; Henderson et al. 2006, 2008). Secondary poisoning risks were shown to be low as were primary poisoning risks to non-targets for those species tested, when compared to brodifacoum (Eason et al. 2002, 2013). Similar low secondary poisoning and non-target risk could be expected for the combination of diphacinone and cholecalciferol.

\section{Discussion}

Brodifacoum is used extensively for sustained ground control of possums and rats on the New Zealand mainland and aerial pest eradication on offshore islands. It is a very effective and important tool for rodent eradication (Broome et al. 2010); however, continuous use of brodifacoum can result in bioaccumulation of residues in non-target wildlife and secondary poisoning risk. Brodifacoum is highly persistent when compared with diphacinone (Eason et al. 1996, 2002, 2010a, 2010b; Fisher et al. 2003; Crowell et al. 2013). The new cereal bait we have described in this publication has the potential to play a key role in controlling possums and rodents alongside other tools for conservation and TB vector management and reduce over-use of brodifacoum, which can result in bioaccumulation of residues in non-target wildlife if it is used continually.

First-generation anticoagulants like diphacinone are effective rodenticides and have also been used to control ferrets in New Zealand (Spurr et al. 2005), but we know these anticoagulants are not effective against possums unless large amounts are eaten (Eason and Jolly 1993; Eason et al. 1994, 2010a, 2010b). Cholecalciferol, a naturally occurring substance (Fairweather et al. 2013), is effective, with lower risk of secondary poisoning or toxicity to birds (Eason et al. 2000, 2013), for controlling rats and possums (Marshall 1984; Eason 1991; Eason et al. 2000, 2010a, 2010b), but has to be used at comparatively high concentrations when used as a sole agent to kill possums and rats (Eason et al. 2010a, 2010b).

We have used the knowledge that a low dose of cholecalciferol will increase the potency of anticoagulant rodenticides (Pospischil and Schnorbach 1994; Kerins et al. 2002; Kocher and Navjot 2013), and built on past research which explored a combination of coumatetralyl and cholecalciferol (Henderson et al. 2008), similar to that previously developed in Europe (Pospischil and Schnorbach 1994). As described in this paper we have produced a new bait with favourable risk versus benefit profile and exploited the low relative persistence of diphacinone versus coumatetralyl, noting the estimated half-life of coumatetralyl is 
56 days in rats versus less than 1 week for diphacinone in rats (Singleton et al. 2003; Kocher and Navjot 2013).

The combination of diphacinone and cholecalciferol in cereal bait has been shown to be both palatable and effective at killing possums, ship rats and potentially mice. The additive effect of a small amount of cholecalciferol with diphacinone was clear when compared to previous results from trials that tested the efficacy of baits containing diphacinone alone, for rodent control (Hix et al. 2010). The average time to death for captive ship rats was approximately two days quicker than that reported for captive rats presented with baits containing just diphacinone at the same concentration (Hix et al. 2010) and two days quicker than captive ship rats dosed with baits containing brodifacoum $(0.002 \%)$ for rat control (Littin et al. 2000). Whilst this result is positive the authors note that the captive animals used in these studies were on reduced rations and full access to food could influence the time to death in the field.

As noted in our review of the welfare literature, brodifacoum is not considered to be humane (Gregory et al. 1998; Littin et al. 2000, 2002, 2009; Eason et al. 2002; O'Connor et al. 2007). We believe the new diphacinone and cholecalciferol bait offers a comparative improvement. The average time to death for captive possums was 5.77 days which is significantly faster than the average of 20.1 days reported for captive possums dosed with brodifacoum baits (Littin et al. 2000), which is important as large amounts of brodifacoum bait can be eaten before death. The intention is that the new bait will be used for controlling possums and rats and not require a professional licence for use so that it is equivalent to second-generation anticoagulants from efficacy and regulatory standpoint. The field trials completed to date have confirmed laboratory results and they have been used to support product registration. The field results also compare favourably to reported kills of rodents using brodifacoum (Innes et al. 1995) and also possums (Henderson et al. 1994); however, there is a lack of published information on the field efficacy of brodifacoum used alone for possums. Larger scale field experience will lead to further optimisation of baiting practices and best practice use. In the future, we believe further research is worth pursuing in three different areas. Firstly, further field trials are warranted to optimise the field use of the new baits. Secondly, unpublished laboratory trials show that a combination bait containing cholecalciferol at half $(0.03 \%)$ or a quarter $(0.015 \%)$ the concentration used in current bait is still effective for killing rats (pers. comm. Lee Shapiro 2018). Hence, where only rodents are being targeted, versus occasions where both possums and rodents are the target, a bait with less cholecalciferol would be suitable, less hazardous and less costly. Thirdly, repeat, resetting toxin delivery systems that exclude non-targets called 'Spitfires' have been shown to have potential, used in a DOC200 trap box (Blackie et al. 2016; Murphy et al. 2018) and preliminary trials with a paste containing diphacinone at $0.005 \%$ and cholecalciferol at $0.06 \%$ killed nine out of ten possums (pers. comm. Lee Shapiro 2018). Targeted delivery using Spitfire devices for rats and possums remains an aspiration for the future (Eason et al. 2017) as they would limit risk to non-target species and complement the development of solid extruded cereal baits containing diphacinone and cholecalciferol described in this paper.

\section{Disclosure statement}

No potential conflict of interest was reported by the authors. 


\section{Funding}

This work was supported by OSPRI; Ministry of Business, Innovation and Employment (MBIE) under [grant number LINX 1003].

\section{ORCID}

James Ross (D) http://orcid.org/0000-0001-7413-4704

\section{References}

Baldwin RA, Meinerz R, Witmer G. 2016. Cholecalciferol plus diphacinone baits for vole control: a novel approach to a historic problem. Journal of Pest Science. 89(1):129-135.

Blackie HM, MacKay JWB, Barret B, Inder S, MacMorran D, Bothwell J, Clout M, Eason C. 2016. A novel device for controlling brushtail possums (Trichosurus vulpecula). New Zealand Journal of Ecology. 40(1):60-64.

Blackwell GL, Potter MA, McLennan JA. 2002. Rodent density indices from tracking tunnels, snaptraps and Fenn traps: do they tell the same story? New Zealand Journal of Ecology. 26:43-51.

Broome K, Murphy E, Cunningham C, Eason CT. 2010. New Zealand's use of brodifacoum in eradication efforts and current investigation of new baits and toxins. In: RM Timm, MB Madon, editor. Proceedings of the 24th vertebrate pest conference. Davis: Published by the University of California; p. 172-177.

Brouwer DA, Beek JV, Ferwerda H, Brugman AM, van der Klis FR, Heiden H, Muskiet FA. 1998. Rat adipose tissue rapidly accumulates and slowly releases an orally-administered high vitamin D dose. British Journal of Nutrition. 79(6):527-532.

Buckle AP, Eason CT. 2015. Control methods: chemical. In: Buckle AP, Smith RH, editor. Rodent pests and their control. 2nd ed. Wallingford (UK): CABI; p. 123-155.

Bullard RW, Thompson RD, Holguin G. 1976. Diphenadione residues in tissues of cattle. Journal of Agricultural and Food Chemistry. 24(2):261-263.

Christensen TK, Lassen P, Elmeros M. 2012. High exposure rates of anticoagulant rodenticides in predatory bird species in intensively managed landscapes in Denmark. Archives of Environmental Contamination and Toxicology. 63:437-444.

Crowell M, Eason CT, Hix S, Broome K, Fairweather A, Moltchanova E, Ross J, Murphy E. 2013. First generation anticoagulant rodenticide persistence in large mammals and implications for wildlife management. New Zealand Journal of Zoology. 40(3):205-216.

Eason CT. 1991. Cholecalciferol as an alternative to sodium monofluoroacetate (1080) for poisoning possums. Proceedings of the 44th NZ Weed and Pest Control Conference. p. 35-37.

Eason CT, Fairweather A, Ogilvie S, Blackie H, Miller A. 2013. A review of recent non-target toxicity testing of vertebrate pesticides: establishing generic guidelines. New Zealand Journal of Zoology. 40(3):217-225.

Eason C, Henderson R, Hix S, MacMorran D, Miller A, Ross J, Ogilvie S. 2010a. Alternatives to brodifacoum for possum and rodent control - how and why? New Zealand Journal of Zoology. 37:175-183.

Eason CT, Henderson R, Thomas M, Frampton C. 1994. The advantages and disadvantages of sodium monofluoroacetate and alternative toxins for possum control. In: Seawright A, Eason CT, editors. Proceedings of the international science workshop on 1080. Christchurch, NZ: The Royal Society of New Zealand Miscellaneous Series. p. 159-166.

Eason CT, Jolly SE. 1993. Anticoagulant effects of pindone in the rabbit and Australian brushtail possum. Wildlife Research. 20:371-374.

Eason CT, Milne L, Potts M, Morriss G, Wright GR, Sutherland O. 1999. Secondary and tertiary poisoning risk associated with brodifacoum. New Zealand Journal of Ecology. 23:219-224.

Eason CT, Murphy EC, Wright GRG, Spurr EB. 2002. Assessment of risks of brodifacoum to nontarget birds and mammals in New Zealand. Ecotoxicology. 11:35-48. 
Eason CT, Ogilvie S, Miller A, Henderson R, Shapiro L, Hix S, Macmorran D. 2008. Smarter pest control tools with low-residue and humane toxins. In: RM Timm, JM O’Brien, editor. Proceedings of the 23rd vertebrate pest conference. Davis: Published by the University of California. p. 148-153.

Eason CT, Ross J, Clapperton K. 2010b. Review of VTA buffer zone specifications for animal procurement, report for ministry of primary industries. Wellington, NZ: New Zealand Food Safety Authority. p. 72.

Eason CT, Shapiro L, Ogilvie S, King C, Clout M. 2017. Trends in the development of mammalian pest control technology in New Zealand. New Zealand Journal of Zoology. 44(4):267-304.

Eason CT, Wickstrom ML, Henderson R, Milne L, Arthur D. 2000. Non-target and secondary poisoning risks associated with cholecalciferol. New Zealand Plant Protection. 53:299-304.

Eason CT, Wright GR, Meikle L. 1996. The persistence of secondary poisoning risks of sodium monofluoroacetate (1080), brodifacoum, and cholecalciferol in possums. In: RM Timm, AC Crabb, editor. Proceedings of the 17th vertebrate pest control conference. Davis: University of California. p. 54-58.

Fairweather A, Eason CT, Arthur D, Eason CMF, Elder P. 2013. Reference concentrations of cholecalciferol in animals - a basis for establishing non-target exposure. New Zealand Journal of Zoology. 40(4):280-289.

Fisher P. 2006. Persistence of residual diphacinone concentrations in pig tissues following sublethal exposure. Wellington: Department of Conservation, DOC Research \& Development Series. 249. p. 9.

Fisher P, O'Connor C, Wright G, Eason CT. 2003. Persistence of four anticoagulant rodenticides in the liver of rats. Department of Conservation, Science Internal Series. 139. p. 19.

Gillies CA, Williams D. 2013. DOC tracking tunnel guide v2. 5.2: Using tracking tunnels to monitor rodents and mustelids. Department of Conservation, Science \& Capability Group, Hamilton, New Zealand. 14 pp.

Gregory NG, Milne LM, Rhodes AT, Littin KE, Wickstrom ML, Eason CT. 1998. Effect of potassium cyanide on behaviour and time to death in possums. New Zealand Veterinary Journal. 46:60-64.

Hayes WJ, Laws ER. 1991. Handbook of pesticide toxicology. San Diego (USA): Academic Press. Inc. p. 1576.

Heaney RP, Horst RL, Cullen DM, Armas LA. 2009. Vitamin D3 distribution and status in the body. Journal of the American College of Nutrition. 28(3):252-256.

Henderson RJ. 2006. The risk to birds from bait containing 'C + C'. Pest-tech Contract Report 2008/ 11. Unpublished Pest-Tech Contract Report PT2008/12. Prepared for Animal Health Board, PO Box 3412, Wellington. 9p.

Henderson RJ. 2009. The risks of primary and secondary poisoning of dogs with ' $\mathrm{C}+\mathrm{C}$ '. Unpublished Pest-tech Contract Report 2009/04. Prepared for Animal Health Board, PO Box 3412, Wellington. p. 34.

Henderson RJ, Frampton CM, Eason CT. 2006. Non-target risks, humaneness and storage/stability of a new chronic pesticide for possum control. Unpublished Pest-Tech Contract Report PT2006/ 04. Prepared for Animal Health Board, PO Box 3412, Wellington. p. 25.

Henderson RJ, Frampton CM, Eason CT. 2008. A review of 'C + C'toxicology. Unpublished PestTech contract report PT2008/07. Prepared for Animal Health Board, PO Box 3412, Wellington. p. 30 .

Henderson RJ, Frampton CM, Thomas MD, Eason CT. 1994. Field evaluations of cholecalciferol, gliftor, and brodifacoum for the control of brushtail possums (Trichosurus vulpecula). Proceedings of the 47th Plant Protection Conference: 112-116.

Hix H. 2009. The effectiveness of a low dose cholecalciferol bait at killing rats and mice. Connovation Limited, Auckland, New Zealand. Internal report. p. 8.

Hix S, Murphy E, Ross J, Shapiro L, Macmorran D, Eason C. 2010. The effectiveness of a single-feed of a bait containing a combination of diphacinone and cholecalciferol bait at killing rats Connovation Ltd Report.

Holick MF. 2003. Vitamin D: a millenium perspective. Journal of Cellular Biochemistry. 88:296307. 
Hollis BW, Burton JH, Draper HH. 1977. A binding assay for 25-hydroxycalciferols and 24R, 25dihydroxycalciferols using bovine plasma globulin. Steroids. 30(2):285-293.

Innes J, Warburton B, Williams D, Speed H, Bradfield P. 1995. Large-scale poisoning of ship rats (Rattus rattus) in indigenous forests of the North Island, New Zealand. New Zealand Journal of Ecology. 19(1):5-17.

Kerins GM, Endepols S, Macnicol AD. 2002. The interaction between the indirect anticoagulant coumatetralyl and calciferol (Vitamin D3) in warfarin resistant rats (Rattus norvegicus). Comparative Clinical Pathology. 11(59):64.

Kocher DK, Navjot K. 2013. Synergistic effect of bromadiolone and cholecalciferol (vitamin D3) against house rat, Rattus rattus. International Journal of Research in BioSciences. 2:73-82.

Langford KH, Reid M, Thomas KV. 2013. The occurrence of second-generation anticoagulant rodenticides in non-target raptor species in Norway. Science of the Total Environment. 450451:205-208.

Lima LL, Salmon TP. 2010. Assessing some potential environmental impacts from agricultural anticoagulant uses. Proceedings 24th Vertebrate Pest Conference. 24. p. 199-203.

Littin KE, Gregory NG, Airey AT, Eason CT, Mellor DJ. 2009. Behaviour and time to unconsciousness of brushtail possums (Trichosurus vulpecula) after a lethal or sublethal dose of 1080 . Wildlife Research. 36:709-720.

Littin KE, O'Connor CE, Eason CT. 2000. Comparative effects of brodifacoum on rats and possums. New Zealand Plant Protection. 53:310-315.

Littin KE, O'Connor CE, Gregory NG, Mellor DJ, Eason CT. 2002. Behaviour, coagulopathy and pathology of brushtail possums (Trichosurus vulpecula) poisoned with brodifacoum. Wildlife Research. 29:259-267.

Livingstone PG, Hancox N, Nugent G, de Lisle GW. 2015. Toward eradication: the effect of Mycobacterium bovis infection in wildlife on the evolution and future direction of bovine tuberculosis management in New Zealand. New Zealand Veterinary Journal. 63(1):4-18.

Lopez-Perea J, Camarero PR, Molina-Lopez RA, Parpal L, Obon E, Sola J, Mateo R. 2015. Interspecific and geographic differences in anticoagulant rodenticide residues of predatory wildlife from the Mediterranean region of Spain. Science of the Total Environment. 511:259-267.

Marshall EF. 1984. Cholecalciferol: a unique toxicant for rodent control. In: Timm R.M, Crabb AC, editor. Proceedings of the 11th vertebrate pest conference. Davis: University of California; p. 95-98.

Morgan DR. 2006. Field efficacy of cholecalciferol gel baits for possum (Trichosurus vulpecula) control. New Zealand Journal of Zoology. 33(3):221-228.

Murphy E, Sjoberg T, Dilks P, Smith D, MacMorran D, Aylett P, Ross J. 2018. A new toxin delivery device for stoats - results from a pilot field trial. New Zealand Journal of Zoology. 45(3):184-191. doi:10.1080/03014223.2018.1461118.

Murray M. 2011. Anticoagulant rodenticide exposure and toxicosis in four species of birds of prey presented to a wildlife clinic in Massachusetts, 2006-2010. Journal of Zoo and Wildlife Medicine. 42:88-97.

NPCA. 2015. Al possum population monitoring using the trap-catch, waxtag and chewcard methods. Wellington: National Pest Control Agencies.

O’Connor C, Littin KE, Milne LM, Airey AT, Webster R, Arthur DG, Eason CT, Gregory NG. 2007. Behavioural, biochemical, and pathological responses of possums (Trichosurus vulpecula) poisoned with phosphorus paste. New Zealand Veterinary Journal. 55:109-112.

Parfitt AM, Gallagher JC, Heaney RP, Johnston CC, Neer R, Whedon GD. 1982. Vitamin D and bone health in the elderly. American Journal of Clinical Nutrition. 36(5):1014-1031.

Parmar G, Bratt H, Moore R, Batten PL. 1987. Evidence for a common binding-site in-vivo for the retention of anticoagulants in rat-liver. Human Toxicology. 6(5):431-432.

Pospischil R, Schnorbach HJ. 1994. Racumin plus, a new promising rodenticide against rats and mice. In: Proceedings of the 16th vertebrate pest conference. Davis: University of California; p. $180-187$.

Prakash I. 1998. Rodent pest management. Boca Raton (FL): CRC Press. p. 480. 
Ruscoe WA, Murphy EC. 2005. House mouse. In: King C.M, editor. The handbook of New Zealand mammals. Auckland: Oxford University Press; p. 204-222.

Salim H, Noor HM, Hamid NH, Omar D, Kasim A, Abdin C. 2015. The effects of rodenticide residues deposited in eggs of Tyto alba to eggshell thickness. Sains Malaysiana. 44:559-564.

Sam S, Ross J. 2012. The efficacy of C + C (cholecalciferol $0.015 \%$ and coumatetralyl $0.03 \%$ ) within a paste and pellet bait on caged possums, Norway rats and mice. Unpublished Lincoln University CWMC Report. p. 6.

Shapiro L, Eason C, Bunt C, Hix S, Aylett P, MacMorran D. 2016. Efficacy of encapsulated sodium nitrite as a new tool for feral pig management. Journal of Pest Science. 89(2):489.

Shapiro L, Hix S, MacMorran D, Eason C. 2011. The effectiveness of a low dose cholecalciferol paste bait at killing Norway rats (Rattus norvegicus) in a cage trial. Connovation Ltd unpublished internal report.

Singleton GR, Hinds LA, Krebs CJ, Spratt DM, editors. 2003. Rats, mice and people: rodent biology and management. Canberra: Australian Centre for International Agricultural Research, Monographs No. 96, 564 p.

Spurr E, Ogilvie S, Morse C, Young J. 2005. Development of a toxic bait for control of ferrets (Mustela furo) in New Zealand. New Zealand Journal of Zoology. 32:127-136.

Stone WB, Okoniewski JC, Stedelin JR. 1999. Poisoning of wildlife with anticoagulant rodenticides in New York. Journal of Wildlife Diseases. 35(2):187-193.

Thijssen HH. 1995. Warfarin-based rodenticides: mode of action and mechanism of resistance. Pesticide Science. 43(1):73-78.

Tobin ME, Matschke CH, Sugihara RT, McCann CR, Koehler AE, Andrews KT. 1993. Laboratory efficacy of cholecalciferol against field rodents. USDA Animal and Plant Health Inspection Services DWRS Research Report No.11-55-002. p. 15.

US Environmental Protection Agency. 2008. Risk mitigation decision for ten rodenticides. Washington, DC: EPA-HQ-OPP-2006-0955-0764. p. 60.

Walker LA, Chaplow JS, Moeckel C, Pereira MG, Potter ED, Shore RF. 2014. Anticoagulant rodenticides in predatory birds 2012: a Predatory Bird Monitoring Scheme (PBMS) report. Centre foe Ecology \& Hydrology, Lancaster, UK. 18pp.

Witmer GM, Moulton RS, Baldwin RA. 2014. An efficacy test of cholecalciferol plus diphacinone rodenticide baits for California voles (Microtus californicus Peale) to replace ineffective chlorophacinone baits. International Journal of Pest Management. 60(4):275-278.

Young J, De Lai L. 1997. Population declines of predatory birds coincident with the introduction of Klerat rodenticide in north Queensland. Australian Bird Watcher. 7:160-167. 